Рекомендована д. фрармац. наук, проф. В. В. Трохимчуком

УДК 615.1:339.13.021:615.32:616.33-002

DOI 10.11603/2312-0967.2018.1.8699

\title{
АНАЛІЗ СЕГМЕНТА ФІТОПРЕПАРАТІВ ДЛЯ ЛІКУВАННЯ ХВОРОБ ШЛУНКОВО- КИШКОВОГО ТРАКТУ НА ФАРМАЦЕВТИЧНОМУ РИНКУ УКРАЇНИ
}

\author{
(c) Л. І. Шульга, К. С. Безкровна, Т. С. Безценна \\ Національний фрармацевтичний університет, Харків \\ shulga_ludmila@ukr.net
}

\begin{abstract}
Мета роботи. Дослідити сегмент лікарських засобів рослинного походження на вітчизняному фармацевтичному ринку, які застосовують для лікування окремих захворювань шлунково-кишкового тракту для встановлення доцільності розробки нового фрітопрепарату.

Матеріали і методи. У роботі використано перелік лікарських засобів за офріційними джерелами інформації, який опрацьовували методами узагальнення, систематизації, графічним, порівняльного та структурного аналізу.

Результати й обговорення. Проведено аналіз фрармацевтичного ринку України щодо асортименту зареєстрованих лікарських засобів рослинного походження для лікування хвороб шлунково-кишкового тракту. Здійснено структуризацію відібраного переліку лікарських засобів за АТС-класифрікацією і встановлено належність їх більшості до фрармакотерапевтичної групи A16AX - «Різні препарати». За виробничою ознакою - більшість лікарських засобів вітчизняного виробництва (86,49 \%). Встановлено незначне превалювання однокомпонентних фітопрепаратів. Визначено, що за агрегатним станом найбільш широко представлені лікарські засоби у вигляді твердих лікарських фрорм (67,57 \%), вагома частка яких - фрасована лікарська рослинна сировина.

Висновки. Досліджено сегмент лікарських засобів рослинного походження на фрармацевтичному ринку України, які призначені для лікування хвороб шлунково-кишкового тракту. Відповідно до результатів аналізу переліку фрітопрепаратів за АТС-класифрікацією, виробничою ознакою, кількістю діючих речовин та лікарською фрормою побудовано макроконтур вивченого сегмента. Незважаючи на присутність на фрармацевтичному ринку пропозицій лікарських засобів рослинного походження для лікування різних захворювань шлунково-кишкового тракту, спостерігається обмеженість асортименту препаратів на основі виділених із лікарської рослинної сировини рослинних субстанцій, що є підставою для пошуку перспективної лікарської рослинної сировини для створення нових рослинних субстанцій та подальшої розробки ліків на їх основі.
\end{abstract}

Ключові слова: фрармацевтичний ринок; фрітопрепарати; рослинні субстанції; шлунково-кишковий тракт.

Вступ. Сьогодні захворювання органів травлення за поширеністю займають третє місце серед різних хвороб та потребують особливої уваги у зв'язку зі збільшенням кількості гастроентерологічних хворих, істотним впливом на стан громадського здоров'я $[1,2]$. Відповідно до статистичних даних, захворювання травної системи становлять 19,2 \% серед дорослого населення України, розповсюдженість хронічного гастриту і дуоденіту у різних країнах коливається від 20-30 до 60-90 \%, а в Україні становить 23,30\% $[1,3,4]$.

Серед поширених захворювань шлунково-кишкового тракту (ШКТ) слід виокремити гастрит та дуоденіт, виразки шлунка та дванадцятипалої кишки, неінфрекційний ентерит та коліт тощо $[3,5]$. У зв'язку 3 високим рівнем розповсюдженості зазначених патологій актуальною залишається розробка нових лікарських засобів (ЛЗ), зокрема, на основі лікарської рослинної сировини (ЛРС).

Фітотерапевтичні засоби широко застосовуються у медичній практиці у фрармакотерапії багатьох захворювань [6-10]. Особливе місце вони займають у комплексі лікувально-профрілактичних заходів у гастроентерологічній практиці, зокрема, у відновлювальний період і для профрілактики рецидивів при їх хронічному перебізі [11-13].

При створенні Лз на першому етапі необхідно обґрунтувати доцільність фрармацевтичної розробки та визначити об'єкти вивчення. Тому важливо дослідити сегмент фрітопрепаратів для лікування захворювань шкТ на фрармацевтичному ринку України $[14,15]$.

Мета роботи - провести дослідження сегмента Л3 рослинного походження, репрезентованих на вітчизняному фрармацевтичному ринку, які застосовують для лікування окремих захворювань ШКТ для обґрунтування доцільності розробки нового фрітопрепарату.

Реалізація визначеної мети передбачала виконання проміжних завдань:

- опрацювання інформаційних джерел і фрормування переліку ЛЗ для подальшого дослідження;

- проведення структурного аналізу асортименту лз за анатомо-терапевтично-хімічною (АТС) класифрікацією, виробничою ознакою, кількістю діючих речовин чи субстанцій, видом лікарської фрорми;

ISSN 2312-0967. Pharmaceutical review. 2018. № 1 
Фармацевтичний менеджмент, маркетинг та логістика Pharmaceutical management, marketing and logistics

- фрормування макроконтуру сегмента фрармацевтичного ринку ЛЗ рослинного походження;

- розгляд площини пропозицій складеного переліку Л3 згідно з показаннями до застосування при гастроентерологічних захворюваннях за Міжнародною класифрікацією хвороб 10 перегляду (MKX-10) [16].

Матеріали і методи. Об'єктами дослідження були зареєстровані на фрармацевтичному ринку України Л3 рослинного походження, які використовують у фрармакотерапії хвороб шкТ у гастроентерології. При дослідженні опрацьовували інфрормацію 3 «Державного реєстру лікарських засобів України» стосовно зареєстрованих в Україні фрітопрепаратів, що представлено на офріційному сайті (станом на 01.01.2017), а також дані електронного довідника «Компендіум лікарські препарати» $[17,18]$.

У ході дослідження застосовано методи узагальнення, систематизації, грасрічний, порівняльного та структурного аналізу.

Результати й обговорення. На підставі аналізу відібраного переліку ЛЗ рослинного походження (37 препаратів) визначено, що Л3 згідно з АТСкласифрікацією належать до різних підгруп АТСгрупи A «Засоби, що впливають на систему травлення і метаболізм».

У таблиці 1 наведено дані щодо розподілу Л3 всередині фрармакотерапевтичної групи А «Засоби, що впливають на систему травлення і метаболізм» із визначенням кількості фрітопрепаратів, які досліджувалися, та їх частки.

На підставі даних внутрішньогрупового аналізу (табл. 1) слід зазначити, що лЗ-об'єкти вивчення $є$ переважно складовими підгрупи A16AX - «Різні препарати», яка належить до підгрупи А16 «Інші засоби, що впливають на систему травлення та метаболічн процеси» та займають 51,35 \% від загальної кількості Л3. Другу позицію за кількістю ЛЗ посідає підгрупа A02X - «اнші засоби для лікування кислотно-залежних захворювань», оскільки містить 24,32 \% об'єктів дослідження. По 8,11\% фрітопрепаратів у підгрупі A02BX - «нші препарати для лікування пептичної виразки і гастроезофрагеальної рефрлюксної хвороби» та у підгрупі A03AX - «Інші препарати, що застосовуються при фрункціональних шлунково-кишкових розладах».

Перелік л3, який було визначено, проаналізовано залежно від країни-виробника ЛЗ, що відображено на рисунку 1.

Відповідно до даних рисунка 1 , левова частка 3 виробництва ЛЗ рослинного походження для застосування при захворюваннях ШКТ належить вітчизняному виробнику (86,49 \%): серед яких понад 50 \% є монокомпонентними ЛЗ.

У групі комплексних ЛЗ національного виробництва окремо можна виділити ЛЗ комбінованого складу, які містять природні та синтетичні діючі компоненти. Так, рослинні складові (крушини кора в порошку, аїру кореневища в порошку) таблеток «Вікаїр» (ПАТ «Галичфрарм» ПАТ «Київмедпрепарат», м. Київ) поєднані з такими речовинами, як вісмуту нітрат основний, магнію карбонат важкий, натрію гідрокарбонат, а діючими речовинами таблеток «Вікалін» (ТОВ «Агрофрарм», м. Ірпінь Київської обл.; ПАТ «Галичфрарм» ПАТ «Київмедпрепарат», м. Київ), окрім вищезазначених рослинних субстанцій крушини та аїру, є наступні компоненти: вісмуту нітрат основний, магнію карбонат, натрію гідрокарбонат, келін тарутин.

Закордонні препарати постачають орармацевтичні виробники з Німеччини («Steigerwald Arzneimittelwerk $\mathrm{GmbH}$ » та «Dr. Gustav Klein GmbH\&Co. KG»), Австралiї «Australian Pharmaceutical Manufecturers Pty Ltd.», Республіки Корея «Dong-A ST Co., Ltd.» та Російської Федерації (ВАТ «Нижсрарм», м. Нижній Новгород). На фрармацевтичному ринку України зареєстровано лише монопрепарати російського та корейського виробника. Німеччина та Австралія пропонують комплексні фрітозасоби, зокрема, ЛЗ «Гастритол Др. Кляйн» «Dr. Gustav Klein GmbH\&Co. KG» (Німеччина), складовими якого $€ 7$ рідких екстрактів (з перстачу гусячого трави, з ромашки лікарської квіток, з солодкикоренів, $з$ дягелю коренів, 3 кардобенедикта трави, з полину гіркого трави, зі звіробою звичайного трави) та комбінований ЛЗ «Ектіс» «Australian Pharmaceutical Manufecturers Pty Ltd.»(Австралія),

Таблиця 1. Структура досліджуваних лЗ за АТС-класифрікацією

\begin{tabular}{|c|c|c|c|}
\hline АТС код & Фармакотерапевтична група & Кількість ЛП & Частка, \% \\
\hline$A 02 X$ & Інші засоби для лікування кислотно-залежних захворювань & 9 & 24,32 \\
\hline A02BX & $\begin{array}{l}\text { Інші препарати для лікування пептичної виразки і гастроезофрагеальної } \\
\text { ресрлюксної хвороби }\end{array}$ & 3 & 8,11 \\
\hline A03AX & $\begin{array}{l}\text { Інші препарати, що застосовуються при фрункціональних шлунково- } \\
\text { кишкових розладах }\end{array}$ & 3 & 8,11 \\
\hline A03ED & Спазмолітики в комбінації з іншими препаратами & 2 & 5,41 \\
\hline A15 & Засоби, що підвищують апетит & 1 & 2,70 \\
\hline $\mathrm{A} 16 \mathrm{AX}$ & Різні препарати* & 19 & 51,35 \\
\hline
\end{tabular}

Примітка. * - у групу віднесено ромашки квітки із АTC-кодом D11AX згідно 3 «Державним реєстром лікарських засобів України».

ISSN 2312-0967. Фармацевтичний часопис. 2018. № 1 


\section{Країна-виробник}

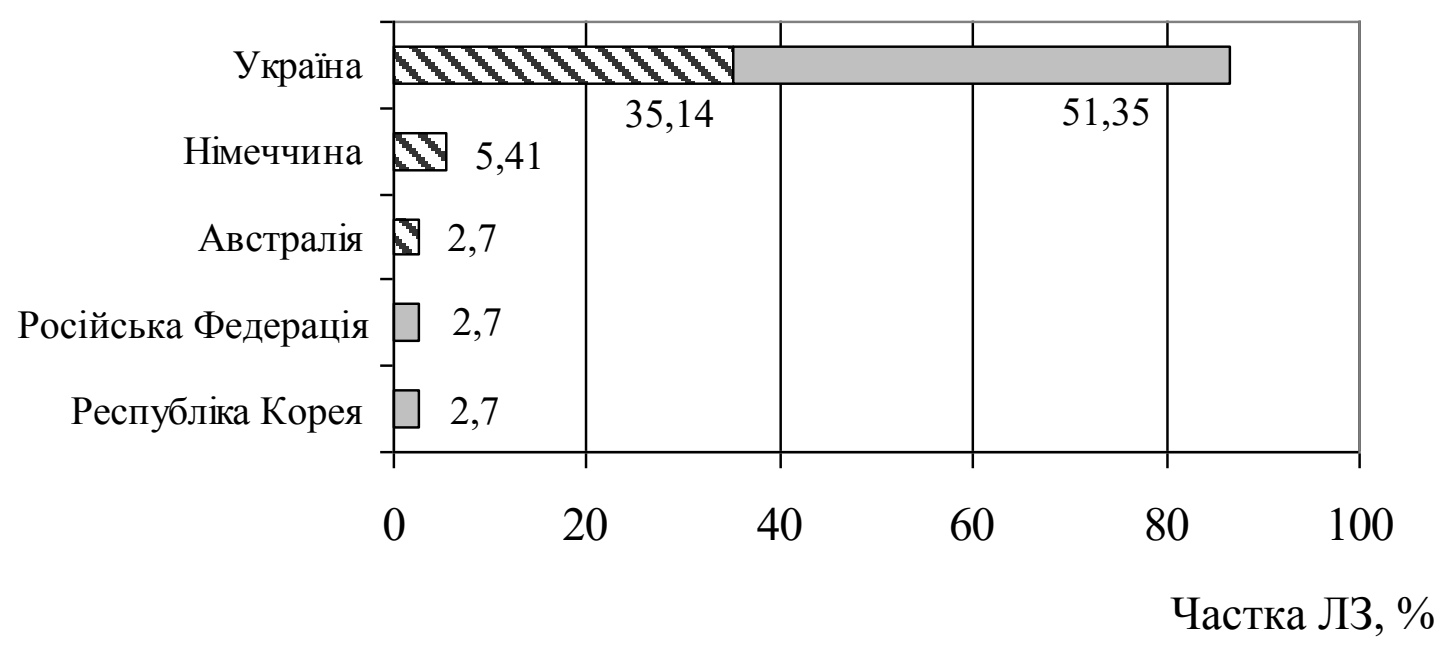

Рис. 1. Розподіл фрітопрепаратів за країною-виробником, де $\square-$ монокомпонентні лз, $\mathbf{\Delta}-$ комплексні Лз.

властивості якого зумовлені діючими речовинами його складу: аскорбіновою кислотою, бромелаіном, інуліном, імбиру кореневищ порошком, артишоку посівного листя сухим екстрактом, журавлини великоплідної соком концентрованим, актинідії китайської плодів сухим екстрактом.

Оскільки за кількістю представлених лз Україна серед країн-постачальників займає провідне місце, доцільно було розглянути виробників та визначити відсоток зареєстрованих Л3 (рис. 2).

Відповідно до одержаних результатів номенклатуру фрітопрепаратів забезпечують 17 вітчизняних виробників, серед яких лідируючі позиції займає ПрАТ «Ліктрави» (м. Житомир), яке постачає $25 \%$ ЛЗ (18,74 \% монокомпонентних, 6,24 \% комплексних) сегмента, який досліджується.

Другу позицію обіймає фрармацевтичне підприємство ПАТ «Лубнифарм» (м. Лубни), яке пропонує 12,48 \% Л3 (по 6,24 \% монокомпонентних і комплексних), а третю - ТОВ «Тернофрарм» (м. Тернопіль), яке $є$ виробником 9,37\% Л3, що вивчалися, серед яких 3,13 \% - це комплексні Л3.

Четверте місце розділяють (по 6,24 \% Л3) наступні вітчизняні виробники - ПрАТ Фармацевтична фрабрика «Віола» (м. Запоріжжя), ПрАТ «Біолік» (м. Ладижин Вінницької обл.), ПАТ «Галичфрарм» (м. Львів). По одній номенклатурній позиції пропонують ЛЗ ще 11 фрармацевтичних підприємств, що сумарно дорівнює $34,43 \%$ (рис. 2).

Наступним кроком роботи було вивчення асортименту Лз за видом лікарської фрорми (ЛФ). 3 відібраного переліку ЛЗ встановлено питому вагу фрітопрепаратів як для монокомпонентних, так і для комплексних Л3, що графрічно представлено на рисунку 3.

На підставі аналізу рисунка 3 можна відмітити, що серед наявних 67,57 \% Л3 - це тверді ЛФ. У широко- му асортименті пропонуються Л3 3 ЛРС (40,54 \%), серед яких 29,73 \% - окремі види фрасованої рослинної сировини, зокрема, «Вільхи супліддя» (ПрАТ «Ліктрави», м. Житомир), Калган (ПрАТ «Ліктрави», м. Житомир), «Ламінарії слані» (ПрАТ «Ліктрави», м. Житомир). Деякі торгові назви представлені у переліку кількома виробниками, а саме «Льону насіння» постачають ПрАТ «Ліктрави» (м. Житомир), ПрАТ Фармацевтична фрабрика «Віола» (м. Запоріжжя), TOB «Тернофрарм» (м. Тернопіль); «Ромашки квітки» - ПрАТ «Ліктрави» (м. Житомир), ПрАТ Фармацевтична фрабрика «Віола» (м. Запоріжжя), ПАТ «Лубнифрарм» (м. Лубни), ТОВ «Тернофрарм» (м. Тернопіль).

10,8 \% складають лікарські рослинні збори: «Гастрофіт» (ТОВ «Науково-виробнича фрармацевтична компанія «ЕЙМ», м. Харків), «Шлунковий збір» (ПАТ «Лубнисрарм», м. Лубни Полтавської обл.), «Фітогастрол» та «Шлунковий збір № 3» (ПрАТ «Ліктрави», м. Житомир).

Наступну позицію після фрасованої ЛРС займають таблетки (16,22 \%): «Альтан» (ПАТ «Науково-виробничий центр «Борщагівський хіміко-срармацевтичний завод», м. Київ), «Вікаїр» (ПАТ «Галичфрарм» ПАТ «Київмедпрепарат», м. Київ), «Вікалін» (ТОВ «Агрофрарм», м. Ірпінь Київської обл.; ПАТ «Галичфрарм» ПАТ «Київмедпрепарат», м. Київ), «Ектіс» (Australian Pharmaceutical Manufecturers Pty Ltd.), «Стилен» (Dong-ASTCo., Ltd.). Меншим асортиментом представлені Л3 у формі супозиторіїв (8,12 \%): «Обліпихова олія» (ВАТ «Нижфрарм», м. Нижній Новгород, РФ), «Обліпихові супозиторії» (ПАТ «Монфрарм», м. Монастирище, Черкаської обл.), а також гранул $(2,7$ \%) - «Плантаглюцид-Здоров'я» (ТОВ «Фармацевтична компанія «Здоров'я», м. Харків).

Майже третина Л3 (32,43 \%) з переліку, що вивчався, виробляється у вигляді рідких ЛФ, серед яких превалю-

ISSN 2312-0967. Pharmaceutical review. 2018. № 1 
Фармацевтичний менеджмент, маркетинг та логістика

Pharmaceutical management, marketing and logistics

\section{Виробники Л3}

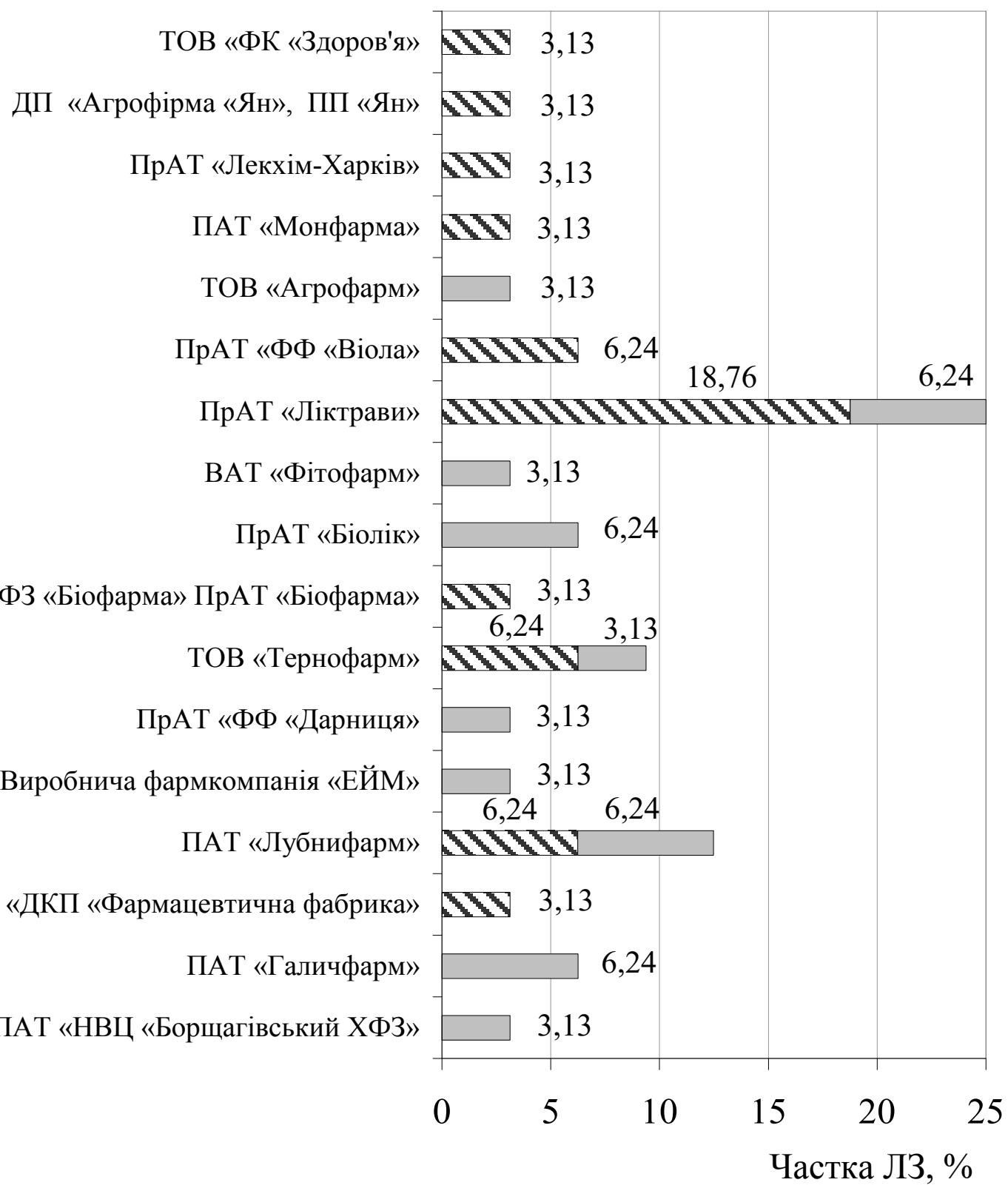

Рис. 2. Кількість пропозицій рослинних ЛЗ досліджуваного сегмента для терапії хвороб шкТ вітчизняних виробників, де $\mathbf{\mathbb { V }}$ - монокомпонентні Л3, $\square$ - комплексні Л3.

ють краплі (10,8 \%), зокрема вітчизняного виробництва: «Гастропін» (ВАТ «Фітофрарм» м. Артемівськ (Бахмут) Донецької обл.), «Шлункові краплі» (ТОВ «Тернофрарм», м. Тернопіль), а закордонного - «Гастритол» «Др. Кляйн» (Dr. Gustav Klein GmbH\&Co. KG), «Іберогаст» (Steigerwald Arzneimittelwerk $\mathrm{GmbH}$ ). Серед асортименту групи рідких ЛЗ окремою позицією представлені рідкі екстракти алое (8,12 \%), які пропонують 3 вітчизняних фрармацевтичних підприємства: ПАТ «Лубнифрарм», м. Лубни Полтавської обл.; ПрАТ «Фармацевтична фрірма «Дарниця», м. Київ; ТОВ «ФЗ «Біофрарма», ПрАТ «Біофрарма», м. Біла Церква Київської обл.
У групі рідких ЛФ представлено: «Бероз», настойку (ПрАТ «Біолік», м. Ладижин Вінницької обл.), «Фітулвент фрітобальзам», бальзам (ПрАТ «Біолік», м. Ладижин Вінницької обл.), «Подорожника сік», рідину (ПАТ «Лубнифарм», м. Лубни Полтавської обл.), «Обліпихи олія» (ТОВ «ДКП «Фармацевтична фрабрика», с. Станишовка Житомирської обл.), «Обліпихова олія» (ДП «Агрофрірма «Ян» ПП «Ян», м. Київ).

На підставі розгляду компонентів у складі лз досліджуваного переліку відзначено, що на основі рослинних субстанцій, які вилучено з ЛРС, виготовлено незначну кількість Лз: таблетки «Альтан» (ПАТ «На-

ISSN 2312-0967. Фармацевтичний часопис. 2018. № 1 
Фармацевтичний менеджмент, маркетинг та логістика Pharmaceutical management, marketing and logistics

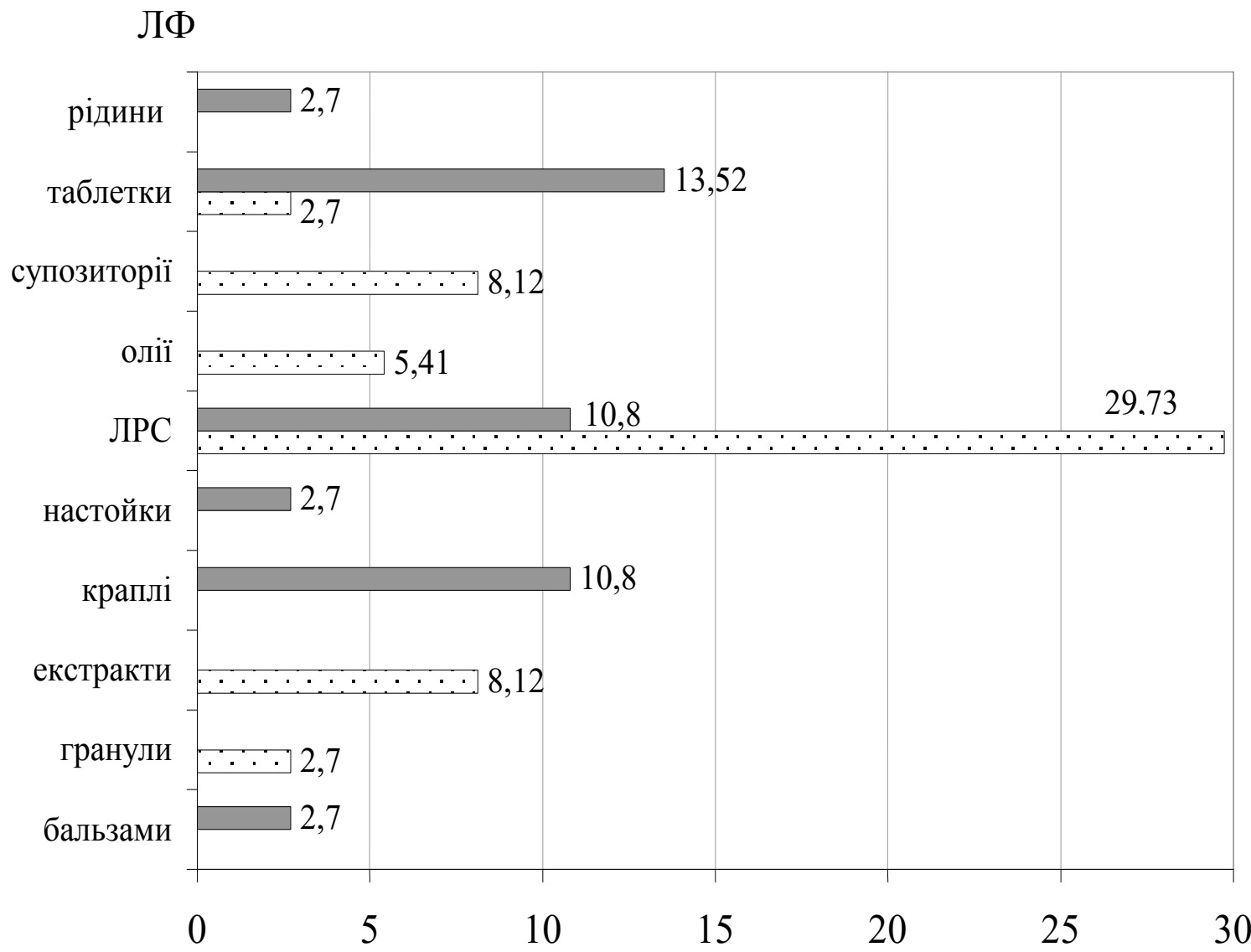

Рис. 3. Питома вага Лз рослинного походження за ЛФ, де $Г \because-$ монокомпонентні ЛЗ, $\square$ - комплексні лЗ.

уково-виробничий центр «Борщагівський хімікофрармацевтичний завод»), що містять очищений екстракт альтан, який одержано з вільхи повислої і вільхи клейкої; таблетки «Ектіс» (Australian Pharmaceutical Manufecturers Pty Ltd., Австралія), складовими яких $є$ сухі екстракти артишоку посівного листя, актинідії китайської плодів, журавлини великоплідної сік концентрований. Алое екстракт сухий є субстанцією для виготовлення таких монокомпонентних Л3, як «Алое екстракт рідкий» (ПАТ «Лубнифрарм», м. Лубни Полтавської обл.) та «Алое екстракт рідкий-Дарниця» (ПрАТ «Фармацевтична фрірма «Дарниця», м. Київ). Екстракт листя полину м'який є діючим компонентом таблеток «Стилен» (Dong-ASTCo., Ltd., Корейська Республіка); олія обліпихова відповідає за фрармакологічну дію ЛЗ у формі супозиторіїв «Обліпихова олія» (ВАТ «Нижфарм», м. Нижній Новгород, Російська Федерація) та «Обліпихові супозиторії» (ПАТ «Монфрарм», м. Монастирище Черкаської обл.).

Відповідно до одержаних результатів дослідження побудовано макроконтур сегмента фрармацевтичного ринку лз рослинного походження, що використовуються для лікування хвороб ШКТ у гастроентерологічній практиці, згідно з яким ЛЗ, що вивчалися, за ATС-класифікацією у більшості $є$ складовими фрар- макотерапевтичної групи A16AX - «Різні препарати»; виготовляються, переважно, вітчизняним виробником (86,49 \%), понад чверть 3 яких постачає фрармацевтичне підприємство ПрАТ «Ліктрави» (м. Житомир). Також встановлено незначне превалювання однокомпонентних ЛЗ рослинного походження $(56,76 \%)$ та визначено, що найбільш широкий асортимент - це ЛЗ у вигляді твердих ЛФ (67,57 \%), майже половина яких - фрасовані види ЛРС (рис. 4).

Обґрунтування доцільності розробки нового ЛЗ передбачає мультивекторні підходи, серед яких дослідження пропозицій сегмента фрітопрепаратів при окремих патологіях ШКТ відповідно до діагностичних критеріїв за МКХ-10, оскільки більшість ЛЗ сформованої групи має декілька показань до застосування і може бути призначена при лікуванні різних нозологічних орорм (рис. 5).

На діаграмі 5 наведено дані щодо розподілу площини пропозицій Лз рослинного походження відносно класів деяких захворювань за MKX-10 у гастроентерології, за якими можна зазначено, що значною мірою представлені лз для лікування таких захворювань ШКТ, як гастрит та дуоденіт (К 29), неінфекційний ентерит та коліт (К 50-К 52), диспепсія (К 30), виразки шлунка (К 25) та дванадцятипалої кишки (K 26).

ISSN 2312-0967. Pharmaceutical review. 2018. № 1 
Фармацевтичний менеджмент, маркетинг та логістика

Pharmaceutical management, marketing and logistics

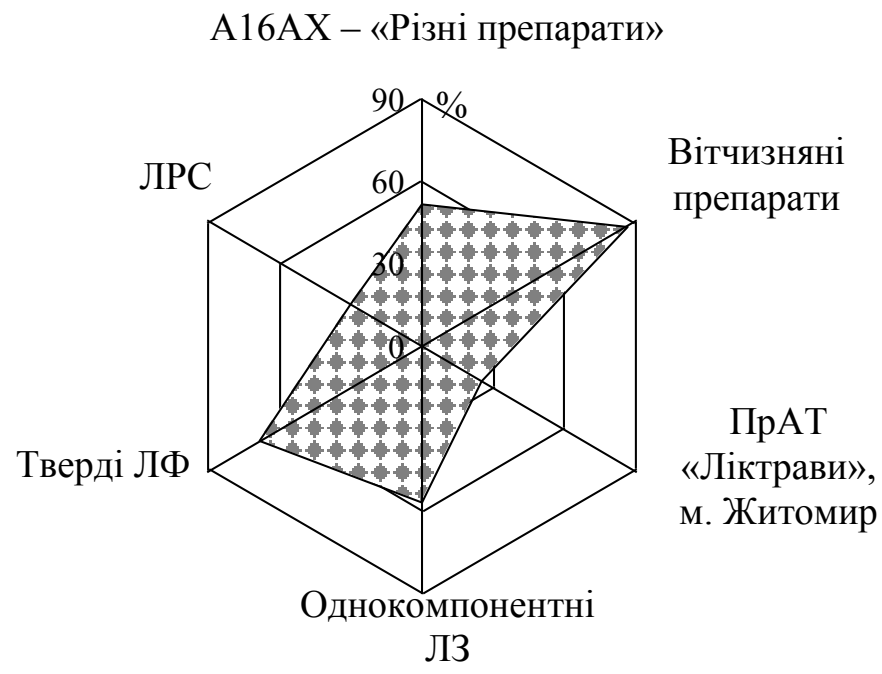

Рис. 4. Макроконтур сегмента фрітопрепаратів фрармацевтичного ринку, які застосовуються при лікуванні захворювань ШКТ.

\section{Класи захворювань (за МКХ-10)}

гастро-езофагеальний рефлюкс (К 21)

інші хвороби стравоходу (К 22)

виразка шлунка (К 25) та виразка

дванадцятипалої кишки (К 26)

гастрит та дуоденіт (К 29)

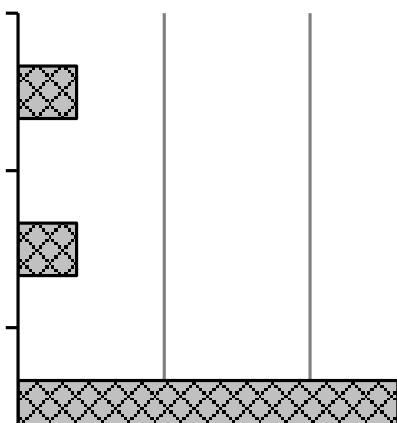

диспепсія (К 30)

неінфекційний ентерит та коліт (К 50-К 52)

синдром подразненого кишечника (К 58)

тріщина та нориця в ділянці заднього

проходу та прямої кишки (К 60)
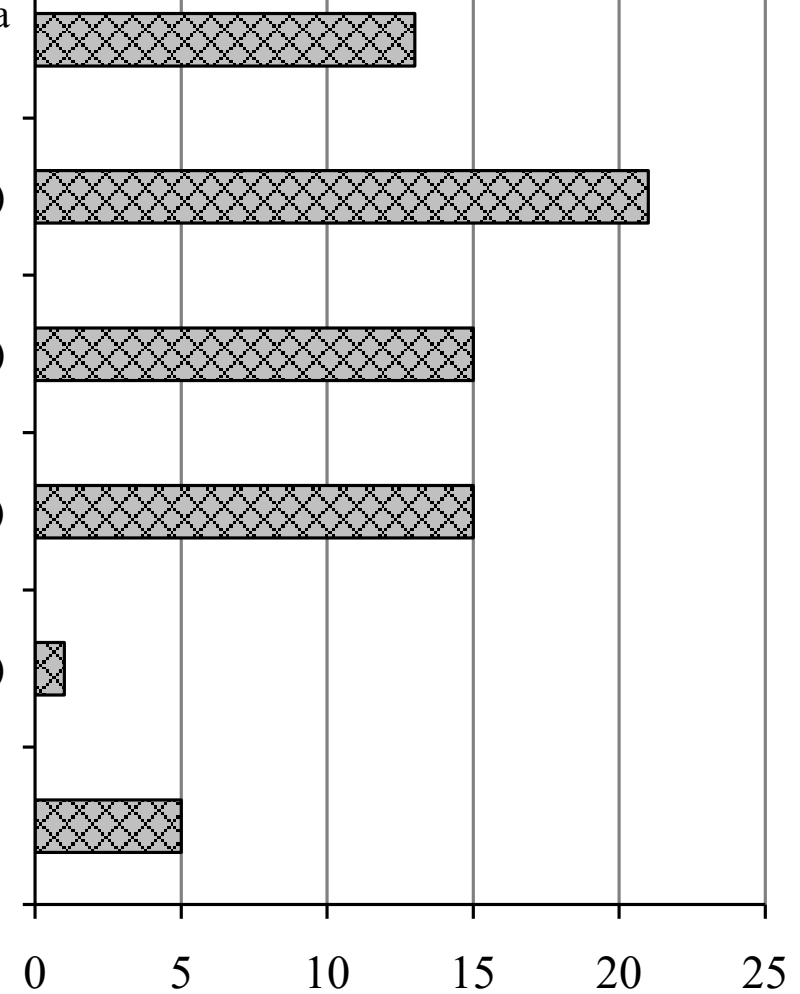

Рис. 5. Розподіл пропозицій л3, які використовуються при лікуванні різних нозологій у гастроентерології згідно з показаннями до застосування.

ISSN 2312-0967. Фармацевтичний часопис. 2018. № 1 
Фармацевтичний менеджмент, маркетинг та логістика Pharmaceutical management, marketing and logistics

Висновки. Розглянуто ЛЗ рослинного походження за АТС-класифрікацією, виробничою ознакою, кількістю компонентів і видом ЛФ. На підставі одержаних результатів побудовано макроконтур сегмента фрітопрепаратів вітчизняного фрармацевтичного ринку, що призначаються у фрармакотерапії хвороб шкТ.

Попри наявність на фрармацевтичному ринку про- позицій ЛЗ рослинного походження для лікування різних захворювань шкТ спостерігається обмеженість асортименту препаратів на основі виділених 3 ЛРС рослинних субстанцій, що виправдовує необхідність пошуку перспективних рослинних об'єктів вивчення 3 метою одержання нових рослинних субстанцій і створення на їх основі нових ЛЗ.

\title{
АНАЛИЗ СЕГМЕНТА ФИТОПРЕПАРАТОВ ДЛЯ ЛЕЧЕНИЯ ЗАБОЛЕВАНИЙ ЖЕЛУДОЧНО- КИШЕЧНОГО ТРАКТА НА ФАРМАЦЕВТИЧЕСКОМ РЫНКЕ УКРАИНЫ
}

\author{
Л. И. Шульга, Е. С. Безкровная, Т. С. Безценная \\ Национальный фрармацевтический университет, Харьков \\ shulga_ludmila@ukr.net
}

Цель работы. Исследовать сегмент лекарственных средств растительного происхождения на отечественном фрармацевтическом рынке, применяемых в лечении отдельных заболеваний желудочно-кишечного тракта, для определения целесообразности разработки нового фритопрепарата.

Материалы и методы. В работе использован перечень лекарственных средств из официальных источников информации, при обработке которого применяли методы обобщения, систематизации, грасрический, сравнительного и структурного анализа.

Результаты и обсуждение. Проанализирован фрармацевтический рынок Украины относительно ассортимента зарегистрированных лекарственных средств растительного происхождения для лечения заболеваний желудочнокишечного тракта. Выбранные лекарственные средства структурированы согласно АТС-классисикации и установлено, что большинство из них принадлежит к фрармакотерапевтической группе A16AX - «Различные препараты». По производственному признаку отмечено большинство лекарственных средств отечественного производства (86,49 \%). Установлено незначительное преобладание однокомпонентных фритопрепаратов. Определено, что по агрегатному состоянию наиболее широко представлены лекарственные средства в виде твердых лекарственных фрорм (67,57 \%), значительная часть которых - фасованное лекарственное растительное сырье.

Выводы. Исследован сегмент лекарственных средств растительного происхождения на фрармацевтическом рынке Украины, которые предназначены для лечения заболеваний желудочно-кишечного тракта. В соответствии с результатами анализа перечня фитопрепаратов по АТС-классифиикации, производственному признаку, количеству действующих веществ и виду лекарственной фрормы сформирован макроконтур исследованного сегмента. Несмотря на наличие на фрармацевтическом рынке предложений лекарственных средств растительного происхождения для лечения различных заболеваний желудочно-кишечного тракта отмечен недостаточно широкий ассортимент препаратов на основе растительных субстанций, полученных из лекарственного растительного сырья, что может быть основанием поиска перспективного лекарственного растительного сырья для создания новых растительных субстанций и дальнейшей разработки лекарственных средств на их основе.

Ключевые слова: фрармацевтический рынок; фритопрепараты; растительные субстанции; желудочно-кишечный тракт.

\section{ANALYSIS OF THE SEGMENT OF PHYTOMEDICINES FOR THE TREATMENT OF DISEASES OF THE GASTROINTESTINAL TRACT ON THE PHARMACEUTICAL MARKET OF UKRAINE}

\section{I. Shulga, K. S. Bezkrovna, T. S. Beztsenna}

National University of Pharmacy, Kharkiv

shulga_ludmila@ukr.net

The aim of the work. To study the segment of herbal drugs in the domestic pharmaceutical market, which are used to treat certain diseases of the gastrointestinal tract to determine the feasibility of developing a new medicines.

Materials and Methods. The work used a list of medicines according to official sources of information, which was studied by generalization, systematization, comparative structural analysis and graphical.

Results and Discussion. The analysis of the pharmaceutical market of Ukraine on the range of registered medical drugs for the treatment of inflammatory diseases of the gastrointestinal tract was conducted. The list of selected drugs

ISSN 2312-0967. Pharmaceutical review. 2018. № 1 
was structured according to ATC-classification, which established the belonging of their overwhelming number to the pharmacotherapeutic group A16AX - «Different drugs». On the basis of manufacturers, most of the drugs of domestic production were noted (86.49\%). An insignificant predominance of single-component medicines was established. It was detected that according to the aggregate condition as the most used produced are the drugs in the solid dosage forms $(67.57 \%)$, the main part of which is medical raw material.

Conclusions. The segment of herbal medicinal products on the pharmaceutical market of Ukraine, which are intended for the pharmacocorrection of inflammatory states of the gastrointestinal tract, was investigated. Due to the results of the analysis of the list of medicines according to the ATC-classification, the production feature, the amount of active substances and the dosage form, the macrocontour of the segment was constructed and studied. Despite the presence in the pharmaceutical market of herbal medicines for the treatment of various diseases of the gastrointestinal tract, the limitations of the assortment of medicines based on plant substances, which are the basis for the search for promising medicinal plant raw materials for the creation of new plant substances and further development of medicines based on them, are established.

Key words: pharmaceutical market; phytomedicines; plant substances; gastrointestinal tract.

\section{Список літератури}

1. Котвіцька А. А. Маркетинговий аналіз асортименту гастроентерологічних лікарських засобів на прикладі інгібіторів протонної помпи / А. А. Котвіцька, В. П. Ходаківська // Фармаком. - 2013. - № 1. - С. 100-106.

2. Рингач Н. О. Хвороби органів травлення: історичні паралелі змін класифікації та епідеміологічної ситуації / Н. О. Рингач, А. О. Керецман // Сімейна медицина. 2015. - № 4 (60). - C. 137-141.

3. Степанов Ю. М. Хвороби органів травлення та гастроентерологічна допомога населенню України: здобутки, проблеми та шляхи їх вирішення / Ю. М. Степанов // Медична газета «Здоров'я України». - 2014. вересень. - С. 10-11.

4. Ткач С. М. Функциональная диспепсия и хронический гастрит: сходство и различия / С. М. Ткач // Гастроентерологія. - 2014. - № 3 (53). - С. 103-108.

5. Intestinal anti-inflammatory activity of the Serpylli herba extract in experimental models of rodent colitis / F. Algieri, A. Rodriguez-Nogales, N. Garrido-Mesa [et al.] // Journal of Crohn's and Colitis. - 2014. - Vol. 8. - P. 775-788.

6. Аналіз номенклатури та складу сучасних лікарських засобів рослинного походження для лікування захворювань сечовидільної системи / Р. М. Лисюк, Р. Є. Дармограй, Н. І. Гудзь, Т. Г. Калинюк // Зб. наук. праць співробіт. НМАПО імені П. Л. Шупика. - 2015. Вип. 24 (4). - С. 264-271.

7. Возможность фритотерапии при заболеваниях системы пищеварения / А. В. Куркина, В. Р. Галямова, В.А.Куркин, Е.В.Авдеева // Фармация и фрармакология. - 2016. - T. 4, № 2 (15). - С. 26-40.

8. Гудзенко А. В. Аналіз ринку багатокомпонентних лікарських засобів рослинного походження, що виявляють ЦНС-тонізуючу активність / А. В. Гудзенко, К. М. Анзіна // Зб. наук. праць співробіт. НМАПО імені П. Л. Шупика. - 2016. - Вип. 26. - С. 162-168.

9. Siddalinga M. S. M. Medicinal plants used in the treat- ment of Gastrointestinal disorders in Bellary district / M. S. M. Siddalinga, G. M. Vidyasagar // Indian J. Tradit. Knowl. - 2013. - Vol. 12 (2). - P. 321-325.

10. Holtmann G. Herbal medicines for the treatment of functional and inflammatory bowel disorders / G. Holtmann, N. J. Talley // Clinical Gastroenterology and Hepatology. 2015. - Vol. 13, No. 3. - P. 422-432.

11. Гудзенко А. В. Вітчизняний ринок багатокомпонентних лікарських засобів рослинного походження: аналіз стану, структура та перспективи розвитку / А. В. Гудзенко, О.О.Цуркан, Т.В.Ковальчук // Фармацевтичний журнал. - 2012. - № 1. - С. 8-12

12. Экспериментальная фрармакотерапия повреждений желудка комплексным растительным средством / С. В. Цыремпилов, Т. А. Ажунова, С. М. Николаев [и др.] // Медицинский вестник Башкортостана. - 2008. T. 3 (6).- C. 54-57.

13. Herbal and plant therapy in patients with inflammatory bowel disease / A. Triantafyllidia, T. Xanthosa, A. Papaloisb, J. K. Triantafillidis // Annals of Gastroenterology. - 2015. Vol. 28. - P. 210-220.

14. Онишків О. І. Аналіз гастроентерологічних лікарських засобів / О. І. Онишків, М. Б. Демчук, Т. А. Грошовий // Фармацевтичний часопис. - 2009. - № 1. - С. 64-69.

15. Саханда І. В. Маркетингові дослідження сучасного стану ринку лікарських засобів рослинного походження / І. В. Саханда // Зб. наук. праць співробіт. НМАПО імені П. Л. Шупика. - 2016. - Вип. 26. - С. 250-254.

16. Міжнародний класифрікатор хвороб МKX-10 [Електронний ресурс]. - Режим доступу : http://mkh10.com.ua/ 17. Державний реєстр лікарських засобів України [Електронний ресурс]. - Режим доступу : http://www.drlz.kiev. ual

18. Компендиум - лекарственные препараты [Електронний ресурс]. - Режим доступу : https://compendium. com.ua/

2. Ryngach NO, Keretsman AO. [Diseases of the digestive system: historical parallels changes in classification andepidemiological situation]. Simeina medytsyna. 2015;4(60):
1. Kotvitska AA, Hodakivska VP. [The marketing analysis of assortment of gastroenterological medicines namely the proton pump inhibitors]. Farmakom. 2013;1: 100-6. Ukrainian.

ISSN 2312-0967. Фармацевтичний часопис. 2018. № 1 
Фармацевтичний менеджмент, маркетинг та логістика Pharmaceutical management, marketing and logistics

137-41. Russian.

3. Stepanov YuM. [Digestive diseases and gastroenterological services to the population of Ukraine: achievements, problems and ways of their solutions]. Medychna hazeta «Health of Ukraine». 2014;sept: 10-11. Ukrainian.

4. Tkach SM. [Functional dyspepsia and chronic gastritis: similarities and differences]. Gastroenterologiya. 2014;3(53): 103-8. Russian.

5. Algieri F, Rodriguez-Nogales A, Garrido-Mesa N, Zorrillaa P, Burkard N, Pischel I, Siever H, Benedek B, Feistel B, Walbroel B, Rodriguez-Cabezas ME, Galvez J. Intestinal anti-inflammatory activity of the Serpylli herba extract in experimenta models of rodent colitis. J Crohn's Colit. 2014;8: 775-88.

6. Lysiuk RM, Darmohrai RYe, Gudz' NI, Kalyniuk TG. [Analysis of the nomenclature and the composition of modern herbal medicines for the treatment of urinary tract diseases]. Zbirnyk naukovykh prats spivrobitnykiv NMAPO imeni PL Shupika. 2015;24(4): 264-71. Ukrainian.

7. Kurkina AV, Galyamova VR, Kurkin VA, Avdeeva EV. [Possibilities of phytotherapy at digestive system diseases]. Farmatsiya i farmakologiya. 2016;4:2(15): 26-40. Russian. 8. Hudzenko AV, Anzina EN. [The market analysis of multicomponent herbal medicinal which exhibit cns-tonic activity]. Zbirnyk naukovyh prats spivrobitnykiv NMAPO imeni PL Shupika. 2016;26: 162-8. Ukrainian.

9. Siddalinga MSM, Vidyasagar GM. Medicinal plants used in the treatment of Gastrointestinal disorders in Bellary district. Indian J Tradit Knowl. - 2013:12(2): 321-5.
10. Holtmann G, Talley NJ. Herbal medicines for the treatment of functional and inflammatory bowel disorders. Clinic Gastroenterol Hepatol. 2015;13:3: 422-32.

11. Gudzenko AV, Tsurkan OO, Kovalchuk TV. [National pharmaceutical market of multicomponent herbal medicines: analysis of the state, the structure and prospects of development]. Farmatsevt zhurnal. 2012;1: 8-12. Ukrainian. 12. Tsyrempilov SV, Azhunova TA, Nikolaev SM, Markaryan AA, Lemza SV. [Experimental pharmacotherapy of stomach injury by complex plant medicine]. Meditsinskiy vestnik Bashkortostana. 2008;3(6): 54-7. Russian.

13. Triantafyllidia A, Xanthosa T, Papaloisb A, Triantafillidis $\mathrm{JK}$. Herbal and plant therapy in patients with inflammatory bowel disease. Annals of Gastroenterology. 2015;28: 21020.

14. Onyshkiv OI, Demchuk MB, Hroshovy TA. [Analysis of market of gastroenterologic preparations]. Farmatsevt chasop. 2009;1: 64-9. Ukrainian.

15. Sakhanda IV. [Marketing research into the modern state of herbal medicines market]. Zbirnyk naukovyh prats spivrobitnykiv NMAPO imeni PL Shupyka. 2016;26: 250-4. Ukrainian.

16. International Classifier of Diseases ICD-10 [Electronic resource]. Available from : http://mkh10.com.ua/

17. Derzhavnyi reiestr likarskykh zasobiv Ukrainy. [Electronic resource]. Available from : http://www.drlz.com.ua 18. Compendium - medicinal preparations. [Electronic resource]. Available from : http://compendium.com.ua 